\title{
Evaluation of circulating CD34+ stem cells in peripheral venous blood in patients with varying degrees of periodontal disease
}

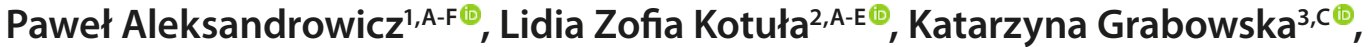

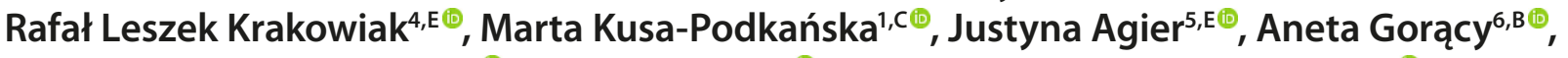 \\ Kinga Eleonora Kądziołka ${ }^{3, E}{ }^{\oplus}$, Janusz Kocki ${ }^{2, E-F}{ }^{\oplus}$, Joanna Wysokińska-Miszczuk ${ }^{1, E-F} \oplus$ \\ ${ }^{1}$ Chair and Department of Peridontology, Medical University, Lublin, Poland \\ 2 Department of Genetics, Medical University, Lublin, Poland \\ ${ }^{3}$ Chair and Department of Neurology, Medical University, Lublin, Poland \\ ${ }^{4}$ Head and Neck Surgery Department Medical University, Lublin, Poland \\ ${ }^{5}$ Department of Experimental Immunology, Medical University, Łódź, Poland \\ ${ }^{6}$ Chair and Department of Haematooncology and Bone Marrow Transplantation, Medical University, Lublin, Poland \\ A - Research concept and design, B - Collection and/or assembly of data, C - Data analysis and interpretation, \\ $D$ - Writing the article, $E$ - Critical revision of the article, F - Final approval of article
}

\begin{abstract}
Aleksandrowicz P, Kotuła LZ, Grabowska K, Krakowiak RL, Kusa-Podkańska R, Agier J, Gorący A, Kądziołka KE, Kocki J, Wysokińska-Miszczuk J. Evaluation of circulating CD34+ stem cells in peripheral venous blood in patients with varying degrees of periodontal disease. Ann Agric Environ Med. 2021; 28(3): 516-520. doi: 10.26444/aaem/125861
\end{abstract}

\section{Abstract.}

Introduction. Periodontal disease presents a challenge for modern medicine, and research on the use of stem cells as a treatment is currently underway.

Materials and method. The study included 45 patients who were given a thorough physical examination. Additionally, an evaluation of their medical history of the disease, degree of progression of periodontal disease, and the level of CRP in the blood was carried out. Patients were divided into 4 groups: 4 patients were in the first group with no periodontal disease, 8 patients in the second group with a moderate level, 20 patients in the third group with an advanced level, and 13 patients in the fourth group were toothless. For each group, the use of stem cells as a treatment of antibody-labeled CD34+ stem cells, lymphocytes, and leukocytes was conducted.

Results. A statistically significant positive correlation was observed in CD34+ stem cells in proportion to lymphocytes in the moderate (0.80), in the advanced (0.75), and in the toothless groups (0.70). The ratio of CD34+ stem cells to leukocytes was statistically significant in the toothless group (0.92) and in the advanced group (0.91). A statistically significant increase was noted in the level of CRP in the previously mentioned groups of patients, and the highest concentration of CD34+ stem cells in the advanced group.

Conclusions. The highest concentration of CD34+ cells was observed in the group of patients with advanced periodontal disease.

\section{Key words \\ periodontitis, periodontal disease, stem cells}

\section{INTRODUCTION}

Periodontal diseases belong to the family of disorders of the ligamentous apparatus of the teeth in the alveolus, including the periodontium, periosteum, alveolar bone, root cementum, and gingiva $[1,2]$. In infected periodontal tissues there are a number of adverse changes, such as migration of the epithelium of the gingival pocket towards the apex of the root, the destruction of periodontal collagen fibres, and an inflammatory resorption of the alveolar bone [3]. The infection usually leads to tooth loss $[4,5]$.

The etiology of periodontal disease is complex. Studies have shown that the main etiological factor is the activity of bacteria that occur in the dental plaque as a result of poor dental hygiene. In addition, the defence mechanisms of the body are triggered by bacterial infection that contribute to the

Address for correspondence: Paweł Aleksandrowicz, Department of Peridontology, Medical University, Karmelicka 7, 20-01, Lublin, Poland

E-mail: pawelalex@tlen.pl

Received: 27.03.2020; accepted: 30.07.2020; first published: 28.08.2020 development of periodontal diseases [6]. Currently, there are no long-term effective treatments for periodontal disease [7].

Stem cells are self-renewing cells that have the potential for unlimited proliferation during their life-time and can differentiate into other cell types $[8,9]$. The CD34+ antigen is a surface glycoprotein belonging to the group of sialomucins typically found in progenitor stem cells. Surface expression is demonstrated by stem cells, bone marrow, cord blood, mesenchymal stem cells, endothelial progenitors, endothelial progenitor cells of the blood vessel, dendritic cell population and VSEL (very small embryonic-like stem cells) [10, 11]. Sialomucin CD34+ involved in stem cells migration [12] is located in the gingival stroma, near the blood vessels and the layer of gingival epithelium, where they penetrate the peripheral blood [13].

Future treatments using stem cells may provide hope for patients with periodontal disorder, which until now could not be treated due to the irreversible degenerative nature of the disease. Although the potential role of stem cells in the treatment of patients is of great interest, for some researchers 
it is a subject of concern and uncertainty concerning their use in possible therapy. A lack of effective methods of treatment for periodontal diseases and advanced involutional changes has led to some research in the evaluation of circulating CD34+ stem cells in patients with varying degrees of periodontal disease.

\section{MATERIALS AND METHOD}

The study material involved the use of peripheral venous blood samples collected from patients who were hospitalized in Independent Public Clinical Hospital No. 4 in Lublin.

Ethical issues. The Bioethics Committee of Lublin Medical University positively evaluated the study protocol (Resolution of the Bioethics Committee No. KE-0254/301.2013). The patients gave written consent for the assessment of their health, medical history and blood sampling for use in laboratory research. The study did not include patients with diseases that may have affected affect the level of stem cells (proliferative disease, acute infection and severe systemic disease).

Assessment of the degree of periodontal diseases. Before participating in the study, all subjects were given a full explanation of the purpose and procedures, and written informed consent was obtained from each patient. All procedures were in line with the Declaration of Helsinki. The study was a cross-sectional analysis of clinical, radiographic, and cytometric data. No clinical trials were involved. Examinations and analysis were conducted in 2015 of the clinical history of the group consisting of 155 patients hospitalized in the Neurology Clinic of the Independent Public Clinical Hospital No. 4 in Lublin. Only non-smokers were included in the study. Children, people aged over 100, as well as patients with an autoimmunological disorder, a cardiovascular disease, acute trauma or acute inflammation excluded from the study. As a result, 45 patients were selected to take part in the study: 23 males and 22 females, aged 50 - 98. Complete medical and dental histories were obtained for all subjects, none of whom had received any periodontal treatment within the last 6 months.

The clinical evaluation of patients and potential predisposing factors (e.g. dyslipidaemia, atherosclerosis, cancer, inflammation) for periodontal disease was performed by a clinical examination, anamnesis, evaluation of the disease history and an imaging examination (craniofacial computed tomography and X-ray study, magnetic resonance imaging of the head).

The diagnosis of patients was based on clinical and radiographic criteria. Clinical parameters including gingival index (GI), probing pocket depth (PD), clinical attachment level (CAL), and bleeding on probing (BOP) were recorded. $\mathrm{PD}$ and $\mathrm{CAL}$ values were obtained using a conventional periodontal probe. Moderate periodontitis is characterized by the loss of 3-4 mm clinical attachment level, and 5-7 mm depth of periodontal pockets. In the case of advanced $p$ the periodontal pockets exceeded $7 \mathrm{~mm}$. As a rule, the test was carried out with a calibrated WHO 621 periodontal probe. All clinical data were collected and recorded by the same examiner.
Preparation of cell suspension - cytometric analysis. The next stage of the study involved peripheral venous blood sampling from the patients. A phenotypic evaluation of the cells found in the suspension of living cells from peripheral venous blood was performed with a cytometer immediately after collection. Neither frozen preparations nor preservatives were used.

Following the protocol, $100 \mu$ l of centrifuged whole peripheral blood with anticoagulant (EDTA) was used, to which $10 \mu \mathrm{l}$ of a CD34 antibody solution labelled with fluorochrome PC5, and $10 \mu \mathrm{l}$ of a CD45 antibody solution labelled with fluorochrome Krome Orang, were added. The cell suspension was then mixed thoroughly and incubated at room temperature for $20 \mathrm{~min}$ in a dark room. To obtain the lysis of erythrocytes, $1 \mathrm{ml}$ of lysis solution (OptiLyse C) was added and the suspension was once again incubated for 20 min without light, in accordance with the manufacturer's instructions. The suspension with the buffered saline solution was then diluted without calcium and magnesium ions.

Cytometric analysis was performed using the NAVIOS 10 COLOR/3 LASER FLOW CYTOMETER (Beckman Coulter, Inc.) under constant physical conditions. Initial grouping of individual cell sub-populations took place in a twodimensional system FS vs. SS (a population of leukocytes and lymphocytes was isolated). The threshold for fluorochrome was set. The risks of contamination influencing the outcome were limited (erythrocytes were lysed, the minimum value for FS was set), and none were detected by the software. The number of individual cell sub-populations was recorded. Photographic documentation was made with the FlowSight ${ }^{\oplus}$ Imaging Flow Cytometer.

The results were labelled (evaluation of the number of cell sub-populations) for a volume of $1 \mu \mathrm{l}$ of blood. Before performing the tests, the cytometer was calibrated using the calibration beads adapted for this device. Sample preparation and gating of the nucleated blood cell sub-populations were performed according to the ISHAGE protocol, which is a standardized international protocol for in vitro diagnostics using flow cytometry of CD $34+$ cells. [14, 15].

Statistical analysis. The study group consisted of 43 patients because this was the smallest number of people allowed to provide data samples for reliable statistical analysis. Statistical analysis was performed using the STATISTICA programme (Statistica 12.5 for Windows). A Microsoft Excel programme was used to store the data collected on each patient's assessment sheet, and to perform statistical calculations with logical functions. The $\mathrm{Chi}^{2}$ test was used for analysis of data on a nominal and ordinal scale and the ShapiroWilk test to check the normality of the variable distribution. In the absence of normal distribution characteristics, the results were analyzed using non-parametric tests. The MannWhitney $U$ test was used to determine the significance of differences between groups and to assess the significance of the differences between the two groups. The Spearman rank correlation test was used to determine the correlation. A result of $\mathrm{p}<0.05$ was considered statistically significant.

\section{RESULTS}

A group of 23 men and 22 women, aged 50-98 years old participated in the study; mean age of all patients -72.75 , 
Table 1. Description of the groups of patients

\begin{tabular}{|c|c|c|c|c|c|}
\hline Group of patients & Healthy & $\begin{array}{c}\text { Moderate } \\
\text { periodontitis }\end{array}$ & $\begin{array}{c}\text { Advanced } \\
\text { periodontitis }\end{array}$ & Toothless & $\mathrm{Chi}^{\wedge} 2$ \\
\hline \multicolumn{6}{|l|}{ Gender } \\
\hline M & $2(4.44 \%)$ & $5(11.11 \%)$ & $7(15.56 \%)$ & $7(15.56 \%)$ & \multirow{2}{*}{$p=0.53$} \\
\hline $\mathrm{F}$ & $2(4.44 \%)$ & $3(6.67 \%)$ & 13 (28.89\%) & $6(13.33 \%)$ & \\
\hline Years & $57-66$ & $57-76$ & $69-84$ & $70-84$ & $p=0.03$ \\
\hline \multicolumn{6}{|l|}{ Marital Status } \\
\hline Maiden/ Bachelor & 0 & $1(2.22 \%)$ & $2(4.44 \%)$ & $1(2.22 \%)$ & \multirow{3}{*}{$p=0.94$} \\
\hline Married & $3(6.67 \%)$ & $3(6.67 \%)$ & $10(22.22 \%)$ & $7(15.56 \%)$ & \\
\hline Widower/ Widow & $1(2.22 \%)$ & $4(8.89 \%)$ & $8(17.78 \%)$ & $5(11.11 \%)$ & \\
\hline \multicolumn{6}{|l|}{ Place Of Residence } \\
\hline Village & 0 & 0 & $6(13.33 \%)$ & $3(6.67 \%)$ & \multirow{3}{*}{$\mathrm{p}=0.31$} \\
\hline $\begin{array}{l}\text { City }<500.000 \\
\text { Inhabitants }\end{array}$ & 0 & 2 (4.44\%) & $1(2.22 \%)$ & $1(2.22 \%)$ & \\
\hline $\begin{array}{l}\text { City }>500.000 \\
\text { Inhabitants }\end{array}$ & $4(8.89 \%)$ & $6(13.33 \%)$ & $13(28.89 \%)$ & $9(20.00 \%)$ & \\
\hline
\end{tabular}

Table 2. Diabetes, lipid disorders, and microangiopathy in different patient's group

\begin{tabular}{lcccc}
\hline Group of patients & Healthy & $\begin{array}{c}\text { Moderate } \\
\text { periodontitis }\end{array}$ & $\begin{array}{c}\text { Advanced } \\
\text { periodontitis }\end{array}$ & Toothless \\
\hline With diabetes & 0 & 1 & 7 & 4 \\
\hline Without diabetes & 4 & 7 & 13 & 9 \\
\hline With dyslipidemia & 2 & 3 & 9 & 8 \\
\hline Without dyslipidemia & 2 & 5 & 11 & 5 \\
\hline With microangiopathy & 3 & 8 & 17 & 10 \\
\hline Without microangiopathy & 1 & 0 & 3 & 3 \\
\hline
\end{tabular}

and median age - 72.35; standard deviation equal to 10.70 . Patients were divided into 4 groups, based on their different dental health conditions: 4 patients with healthy dental health, 8 patients with moderate periodontitis, 20 patients with advanced periodontitis, and 13 patients who were toothless.

Patients were categorized using basic epidemiological data, such as age, gender, marital status (maiden/bachelor, married, widower/widow) and place of residence: village, city $<500,000$ inhabitants, city $>500,000$ inhabitants. (Tab. 1). The results did not show significant differences related to age or gender between dental health groups, with the exception of the 'advanced peridontitis' group.

Patients' data were also taken into consideration to identify other contributing factors that could also affect the occurrence of periodontal diseases (diabetes, lipid disorders, and microangiopathy) (Tab. 2). Female patients were also evaluated based on the impact of hormonal (preand postmenopausal) changes on the condition of the oral cavity, although no significant differences were seen.

Due to the small number of patients in each group, no statistically significant relationships were found in systemic predispositions for periodontal disease, according to $\mathrm{Chi}^{2}$ Pearson and $\mathrm{Chi}^{2} \mathrm{NW}$ tests. The level of c-reactive protein (CRP) in the peripheral blood of patients was determined (Tab. 3).

Using a flow cytometer with fluorochrome labeled antibodies, the number of CD34+ stem cells, leukocytes, and lymphocytes was determined. The results were analyzed in pairs using the Spearman rank (rs) order. The correlation
Table 3. CRP level in different groups of patients

\begin{tabular}{lcccc}
\hline Group of patients & Healthy & $\begin{array}{c}\text { Moderate } \\
\text { periodontitis }\end{array}$ & $\begin{array}{c}\text { Advanced } \\
\text { periodontitis }\end{array}$ & Toothless \\
\hline CRP level & 15.37 & 17.02 & 20.13 & 15.37 \\
\hline
\end{tabular}

between particular laboratory parameters was evaluated and statistically significant results were found at the significance level of $\mathrm{p}<0.05$.

In the group of toothless patients, a statistically significant positive correlation of the percentage of CD34+ cells in relation to leukocytes $\mathrm{CD} 45+(\mathrm{rs}=0.92)$ was found, which was lower in relation to lymphocytes $(r s=0.71$, and the percentage of cells CD34+ to lymphocytes in relation to percentage of $\mathrm{CD} 34+$ cells to leukocytes CD45+ ( $\mathrm{rs}=0.66)$.

In the group of patients with moderate periodontal disease, there was a statistically significant positive correlation of lymphocytes $(\mathrm{rs}=0.79), \mathrm{CD} 34+$ cells $(\mathrm{rs}=0.81)$ and $\mathrm{CD} 34+$ cells/lymphocytes $(\mathrm{rs}=0.81)$ in relation to the number of all leukocytes to the percentage of CD34+/WBC cells, compared to $\mathrm{CD} 34+$ cells $(\mathrm{rs}=0.93)$ and percentage of CD34+/lymphocytes ( $\mathrm{rs}=0.93$ ).

In the group of patients with advanced periodontal disease, statistically significant positive correlations of CD34+ cell numbers were found relative to CD34+ cells / lymphocytes ( $\mathrm{rs}=0.75$ ), and the correlation was stronger in the percentage of CD34+ cells / leukocytes CD45+ (rs =0.91), and percentage of CD34+ cells / lymphocytes to percentage of cells CD34+ / leukocytes CD45+ ( $\mathrm{rs}=0.67)$.

There were no statistically significant differences in the number of stem cells between the groups. The only statistically significant value was of the CRP level in the group of toothless patients, with moderate and advanced periodontal diseases (Fig. 2).

\section{DISCUSSION}

The periodontium is a small source of mesenchymal stem and progenitor cells in the body of an adult human $[16,17,18]$. In addition, stem cells from the alveolar process have the ability to participate in the regeneration process, without the need for invasive methods $[19,20]$. These cells are multipotent cells and can differentiate into fibroblasts, osteoblasts, adipocytes, chondrocytes, and dental ligaments cells [17, 21, 22].

The study presents results related to conditions that predispose to the development of periodontal diseases, such as old age and systemic disorders, e.g. diabetes, dyslipidaemia, microangiopathy and inflammation (CRP level). Many results show positive correlations with systemic diseases, in particular diabetes or other hormonal imbalances [23, $24,25,26]$. In the current study, no statistically significant difference were found between any of the patient groups, except for the level of CRP protein in the group of patients with advanced periodontopathy. However, in this study, statistically significant results were obtained of stem cells differentiating into inflammatory cells. The highest lymphocyte count was noted in the group of toothless patients, which may be associated with changes in nutrition and supply of adequate amounts of nutrients (deficiencies of vitamins and mineral salts), cessation of proper oral hygiene (not using rinsing liquids), and colonization of bacteria and oral fungi. $[27,28,29]$. 


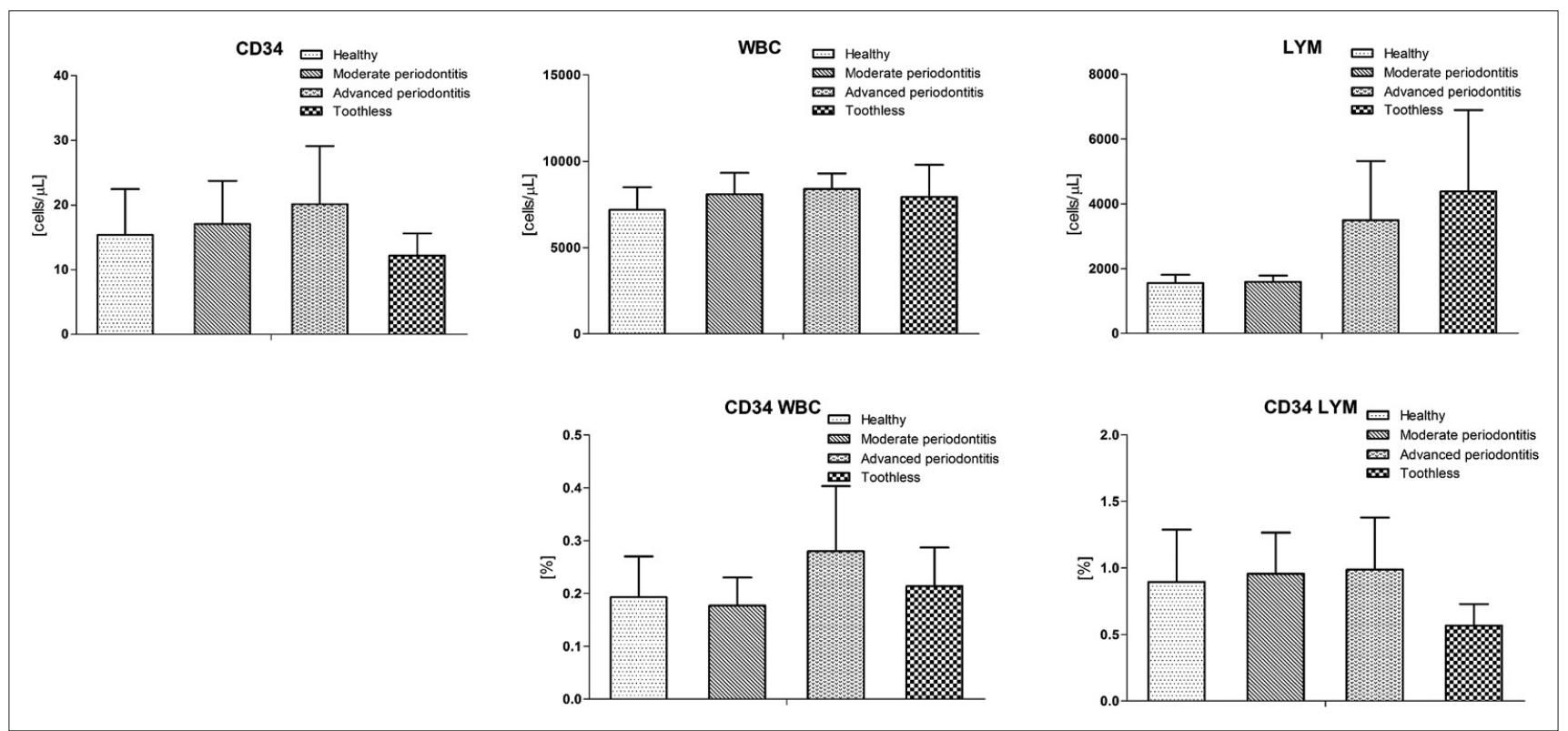

Figure 1. Level of cells CD34+, WBC, Limfocytes (up) and cells ratio CD34+ WBC, cells ratio CD34+ Limfocytes (down)

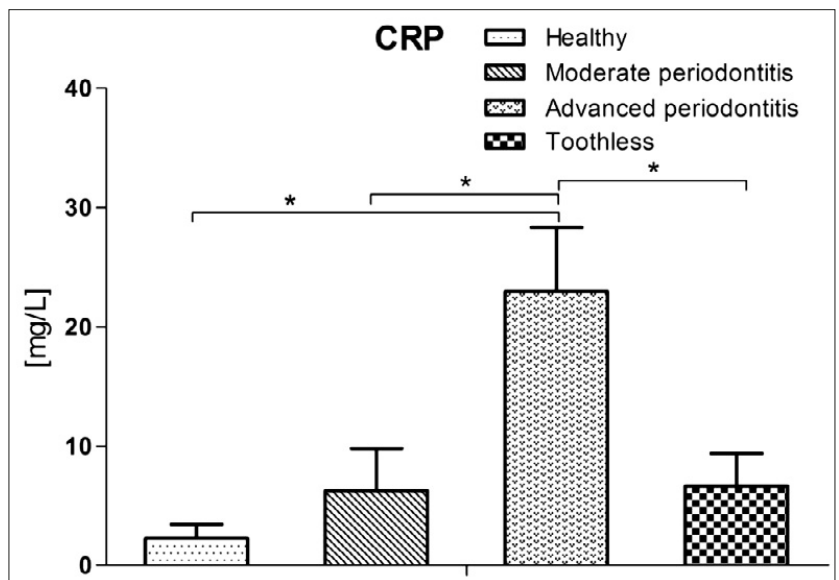

Figure 2. CRP level in the different group patientes

The study also evaluated the CD34+ stem cells circulating in peripheral blood. But no statistically significant differences were observed between the different groups of patients, or differences in the ratio of $\mathrm{CD} 34+$ cells to the total number of peripheral blood lymphocytes. Bullon et al. also did not observe any statistically significant differences between a group of patients with advanced periodontal disease and a group of healthy patients [30]. However, they they observed the biggest population of $\mathrm{CD} 34+$ cells in the group of patients with peri-implant infection. Li et al. obtained similar results, which confirms the reduction of the number of CD34+ cells to peripheral blood lymphocytes in patients after a halfyearly treatment of periodontal disease [31]. In the presented study, the majority of CD34+ cells occurred in the advanced group (Fig. 1), whereas in the Baddam's study a statistically higher number of progenitor cells of CD 34+ in periodontal tissues was observed in the group of patients with chronic periodontitis, especially in patients with type 2 diabetes [32].

Due to the lack similar research in the literature, it is difficult to compare the results obtained in the current study with those obtained in other centres. Because of the small research group, further research should be carried out on a larger group of patients. In the future, the authors also plan to include more clinical parameters and results of laboratory research. The results of the cytometric analysis are affected not only by periodontal diseases, but also by other systemic diseases (tumours, inflammatory conditions, acute conditions, e.g. myocardial infarction or stroke). Therefore, of the 155 patients originally included in the study, after careful clinical examination only 45 were qualified to be included in the final statistical analysis.

Nowadays, periodontal disease is a big challenge facing many therapists. At present, no effective treatments and prevention methods exist, which in addition to the lack of an insufficient number of scientific publications, led the authors to undertake the presented study in an attempt to analyze the potential future use of stem cells in treating periodontal diseases $[33,34]$. Unfortunately, the presented study alone is insufficient, therefore evaluations of other sub-populations of stem cells in the treatment of patients with periodontal diseases are planned. A follow-up study should involve a bigger group of patients, and an evaluation of the possible role of $\mathrm{CD} 34+$ progenitor cells in patients with chronic periodontitis.

\section{CONCLUSIONS}

The highest concentration of CD34+ cells was observed in the group of patients with advanced periodontal disease.

No conditions were found that predisposed to periodontopathy, except in the group with advanced periodontopathy, where high CRP levels were observed which seems to be a secondary rather than a primary consequence of periodontitis.

\section{REFERENCES}

1. Tang J, Saito T. The Role of Nephronectin on Proliferation and Differentiation in Human Dental Pulp Stem Cells. Stem Cells International. Article ID 2546261, 2017. doi: 10.1155/2017/2546261

2. Park JY, Chung JH, Lee JS, Kim HJ, Choi SH, Jung UW. Comparisons of the diagnostic accuracies of optical coherence tomography, micro- 
computed tomography, and histology in periodontal disease: an ex vivo study. J Periodontal Implant Sci. 2017; 47(1): 30-40. doi: 10.5051/ jpis.2017.47.1.30

3. Coretti L, Cuomo M, Florio E, Palumbo D, Keller S, Pero R, et al. Subgingival dysbiosis in smoker and non smoker patients with chronic periodontitis. Mol Med Rep. 2017; 15(4): 2007-2014. doi: 10.3892/ mmr.2017.6269

4. Castro SA, Collighan R, Lambert PA, Dias IH, Chauhan P, Bland CE, et al. Porphyromonas gingivalis gingipains cause defective macrophage migration towards apoptotic cells and inhibit phagocytosis of primary apoptotic neutrophils. Cell Death Dis [accessed 2 March 2017] 2017; 8(3): e2644. doi: 10.1038/cddis.2016.481

5. Chinthamani S, Settem RP, Honma K, Kay JG, Sharma A. Macrophage inducible C-type lectin (Mincle) recognizes glycosylated surface (S) layer of the periodontal pathogen Tannerella forsythia. PLoS One [accessed 6 March 2017]; 2017; 12(3): e0173394. doi: 10.1371/journal. pone. 0173394

6. Äyräväinen L, Leirisalo-Repo M, Kuuliala A, Ahola K, Koivuniemi $\mathrm{R}$, Meurman JH, Heikkinen AM. Periodontitis in early and chronic rheumatoid arthritis: a prospective follow-up study in Finnish population. BMJ Open 2017 [accessed 31 January 2017]; 2017; 7: e011916. doi: 10.1136/bmjopen-2016-011916

7. Chalisserry EP, Nam SY, Park SH, Anil S. Therapeutic potential of dental stem cells. Journal of Tissue Engineering. 2017; 8: 2041731417702531. doi: /10.1177/2041731417702531

8. Serakinci N, Keith WN. Therapeutic potential of adult stem cells. Eur J Cancer. 2006; 42: 1243-1246.

9. Sidney LE, Branch MJ, Dunphy SE, Dua HS, Hopkinson A. Concise review: evidence for CD34 as a common marker for diverse progenitors. Stem Cells. 2014; 32(6): 1380-1389. doi:10.1002/stem.1661

10. Park KS, Pang B, Park SJ, Lee YG, Bae JY, Park S, et al. Identification and Functional Characterization of Ion Channels in CD34+ Hematopoietic Stem Cells from Human Peripheral Blood. Mol Cells. 2011; 32: 181-188.

11. Strilić B, Kucera T, Eglinger J, Hughes MR, McNagny KM, Tsukita S, et al. The molecular basis of vascular lumen formation in the developing mouse aorta. Developmental Cell. 2009; 17(4): 505-515. doi: 10.1016/j. devcel.2009.08.011

12. Lavu V, Padmavathy R, Rao SR. Immunolocalization of CD34 positive progenitor cells in healthy human gingival. A pilot study. Indian Med Res. 2009; 129: 685-689.

13. Sutherland RD, Anderson L, Keeney M, Chin-Yee I, The ISHAGE guidelines for CD34+ cell determination by Flow cytometry. Jun J Hematother Stem Cell Res. 1996; 5(3): 213-226.

14. Keeney M, Chin-Yee I, Weir K, Popma J, Nayar R, et al. Single platform flow cytometric absolute CD34+ cell counts based on the ISHAGE guidelines. International Society of Hematotherapy and Graft Engineering. Cytometry. 1998; 34(2): 61-70.

15. Bartold PM, Shi S, Gronthos S. Stem cells and periodontal regeneration. Periodontol 2000. 2006; [accessed 4 January 2006]; 40: $164 \mathrm{e} 172$.

16. Shokoofeh J. Massoumeh Z. Ghodratollah R. Fatemeh H. Ali Dehghani| $\mathrm{N}$. Immunohistochemical Comparison of the Expression of CD34 and CD105 in Odontogenic Keratocyst and Dentigerous Cyst J Dent. 2017; Mar; 18(1): 43-49.

17. Gronthos S, Arthur A, Bartold PM, Shi S. A method to isolate and culture expand human dental pulp stem cells. Methods Mol Biol. 2011; 698: 107e121.
18. Wang L, Shen H, Zheng W, Tang L, Yang Z, Gao Y, et al. Characterization of stem cells from alveolar periodontal ligament. Tissue Eng Part A 2010; [accessed 27 December 2011]; 17: 1015e1026.

19. Zhou Y, Hutmacher DW, Sae-Lim V, Zhou Z, Woodruff M, Lim TM. Osteogenic and adipogenic induction potential of human periodontal cells. J Periodontol. [accessed 1 March 2008]; 2008; 79: 525e534.

20. Xu J, Wang W, Kapila Y, Lotz J, Kapila S. Multiple differentiation capacity of STRO-1+/CD146+ PDL mesenchymal progenitor cells. Stem Cells Dev. [accessed 18 April 2009]; 2009; 18: 487e496.

21. Harasymiak-Krzyżanowska I, Niedojadło A, Karwat J, Kotuła L, Gil-Kulik P, Sawiuk M, et al. Adipose tissue-derived stem cells show considerable promise for regenerative medicine applications. Cell Mol Biol Lett. 2013; 18(4): 479-93. doi: 10.2478/s11658-013-0101-4

22. Nibali L, D'Aiuto F, Griffiths G, Patel K, Suvan J, Tonnetti MS. Severe periodontitis is associated with systemic inflammation and dysmetabolic status. A case control study. J Clin Periodontol. 2007; 34: 931-937.

23. D’Aiuto F, Graziani F, Tete S, Gabriel M, Tonnetti MS. Periodontitis: from local infections to systemic diseases. Int J Immunopath Pharmac. 2005; 18: 1-11.

24. Mealy BL. Periodontal disease and diabetes. J Am Dent Association. 2006; 137: 26-31S.

25. Raczkiewicz D, Owoc A, Wierzbińska-Stępniak A, Bojar I. Metabolic syndrome in peri- and postmenopausal women performing intellectual work. Ann Agric Environ Med. 2018; 25 (4): 610-615.

26. Bakar A, Ningrum V, Parlindungan A, Wulandari T, Shih-Chieh Lee, Acute pseudeomembran candidiasis in a patient with high erythrocyte dedimentation rate and leucocyte. Conference: Proceedings of the Third Workshop on Multidisciplinary and Its Applications, WMA-3 2019, 11-14 December 2019

27. Fleming CR, Witzke DJ, Beart RW. Catheter-related complications in patients receiving home parenteral nutrition. Ann Surg. 1980 Nov; 192(5): 593-599. doi: 10.1097/00000658-198011000-00002.

28. Ignatavicius DD, WorkmanL, Rebar Ch. Medical-Surgical Nursing E-Book: Concepts for Interprofessional Collaborative Care, Elsevier Health Sciences, 2017; p. 1218.

29. Bullon P, Fioroni M, Goteri G, Rubini C, Battino M. Immunohistolchemical analysis of soft tissues in implants with healthy and periimplantitis condition, and aggressive periodontitis. Clin Oral Implants Res. 2004; 15(5): 553-559.

30. Li X, Tse HF, Yiu KH, Li LS, Jin L. Effect of periodontal treatment on circulating CD34(+) cells and peripheral vascular endothelial function: a randomized controlled trial. J Clin Periodontol. 2011; 38(2): 148-56.

31. Baddam S, Penmetsa G, Mandalapu N, DV S, Mannem R, Alla RK, et al. Immunolocalization of CD34 Positive Progenitor Cells in Diabetic and Non-Diabetic Periodontitis Patients - A Comparative Study. J Clin Diagn Res. 2014; 8(11): 96-99. doi: 10.7860/JCDR/2014/9827.5191

32. Fa-Ming C, Li-Na G, Bei-Min T, Xi-Yu Z, Yong-Jie Z, et al. Treatment of periodontal intrabony defects using autologous periodontal ligament stem cells: a randomized clinical trial. Stem Cell Res Ther. 2016; 7: 33. doi: 10.1186/s13287-016-0288-1

33. Li X, Tse HF, Yiu KH, Li LS, Jin L. Effect of periodontal treatment on circulating CD34(+) cells and peripheral vascular endothelial function: a randomized controlled trial. J Clin Periodontol. 2011; 38(2): 148-56. doi: 10.1111/j.1600-051X.2010.01651.x 